\title{
Kertomus Kotikielen Seuran 143. toimintavuodesta
}

Seura on perustettu vuonna 1876. Sen tehtävänä on edistää suomen kielen tutkimusta, tuntemusta ja käyttöä. Tällä hetkellä keskeisimpiä toimintamuotoja ovat aikakauslehti Virittäjän julkaiseminen sekä kokousten ja symposiumien järjestäminen. Lisäksi Seura myöntää vuosittain rahastoistaan apurahoja ja palkintoja.

Sadantenaneljäntenäkymmenentenäkolmantena toimintavuotenaan Kotikielen Seura on kokoontunut kolme kertaa. Kokouksissa on käynyt keskimäärin 24 henkeä.

Vuosikokouksessa 14. maaliskuuta 2018 Tiedonkerronta-hanke, johon kuuluvat professori Pirjo Hiidenmaa, tohtori Mikko T. Virtanen sekä maisterit Henri Satokangas, Elina Vitikka ja Ilona Lindh, esitelmöi aiheesta Tiedonkerronta - tietokirjallisuuden tutkimusta.

Toukokuun 9. päivänä 2018 Kotikielen Seura järjesti Kielitieteen päivien yhteydessä Suomen kielitieteellisen yhdistyksen kanssa paneelikeskustelun uuden tietosuoja-asetuksen vaikutuksista kielitieteellisten aineistojen tilanteeseen.

Syyskuun 27. päivänä 2018 kuultiin ansioituneisiin pro gradu -töihin pohjautuvia esitelmiä. Maisteri Eeva Attila esitelmöi aiheesta "Miksi tämän lain valvonnasta vastaa Elintarviketurvallisuusvirasto? Ei-modaalinen indikatiivi säädöskielessä”, maisteri Kertu Güngörmez aiheesta "Noh menoks! Davai! Let's go! Monikielistä koodinvaihtoa videopelien pelaamisen aikana", maisteri Jenni Järvinen aiheesta "Naisen euro -konstruktio - muoto, merkitys ja erilaiset ilmentymät" ja maisteri Emma Koistinen aiheesta "Kieli-ideologiat ärsyttävien sanojen taustalla".

Marraskuun 29. päivänä 2018 dosentti Hanna Lappalaisen ja professori emerita Pirkko Nuolijärven johtama tutkimushanke "Sata suomalaista kielellistä elämäkertaa" esittäytyi. Professori emeritus Heikki Paunonen esitelmöi aiheesta "Mistä kaikki sai alkunsa?", dosentti Hanna Lappalainen, professori emerita Pirkko Nuolijärvi ja kandidaatti Outi Pajukallio aiheesta "Sata suomalaista kielellistä elämäkertaa -projekti: tavoitteet, aineisto ja nykyvaihe", tohtori Kaarina Mononen ja dosentti Hanna Lappalainen aiheesta "Opiskelijat aineistoa keräämässä - haastattelukokemusten tarkastelua", professori emerita Pirkko Nuolijärvi aiheesta "Ensi havaintoja suomen kielen variaatiosta 2010-luvun lopulla" ja maisteri Anniina Asikainen aiheesta "Työelämän kieltä eri näkökulmista - kahden ikäryhmän kieliasenteiden tarkastelua".

Seuran esimiehenä on toiminut professori Pirjo Hiidenmaa, ensimmäisenä varaesimiehenä tohtori Mari Siiroinen, toisena varaesimiehenä professori Jyrki Kalliokoski, sihteerinä maisteri Henri Satokangas, varasihteerinä maisteri Elina Vitikka, rahastonhoitajana maisteri Toni Suutari sekä muina johtokunnan jäseninä tohtori Pilvi Heinonen, tohtori Yrjö Lauranto ja maisteri Katriina Rapatti.

Toiminnantarkastajina ovat olleet tohtori Annakaisa Pohjola ja maisteri Nico Wendelin sekä varatoiminnantarkastajina tohtori Salli Kankaanpää ja tohtori Ritva Pallaskallio. Kirjanpidosta on vastannut Aallon tilitoimisto.

Seuran johtokunta on kokoontunut toimintavuoden aikana 4 . huhtikuuta 2018, 3. toukokuuta 2018, 12.-15. kesäkuuta 2018, 20. syyskuuta 2018, 27.29. marraskuuta 2018, 14. joulukuuta 2018, 30. tammikuuta - 13. helmikuuta 2019 ja 28. helmikuuta 2019 eli yhteensä 8 kertaa. Seurassa oli vuoden 2018 lopussa kuusi kunniajäsentä ja 646 jäsenmaksunsa maksanutta vuosijäsentä. Painetun Virittäjä-lehden jäsentilaajia oli 508 
(täysjäseniä 213 ja opiskelijajäseniä 295) ja verkkolehden tilaajia 64 (täysjäseniä 32 ja opiskelijajäseniä 32). Virittäjää tilaamattomia jäseniä oli 74 (täysjäseniä 50 ja opiskelijajäseniä 24). Seuraa on edustanut Tieteellisten seurain valtuuskunnan syyskokouksessa Mari Siiroinen sekä Suomen tiedekustantajien liiton vuosikokouksessa Hanna Lappalainen.

Kokouksessaan 15. helmikuuta 2019 August Ahlqvistin, Yrjö Wichmannin, Kai Donnerin ja Artturi Kanniston rahastojen yhteinen lautakunta, johon ovat kuuluneet Suomalais-Ugrilaisen Seuran edustajina professori Riho Grünthal, professori Sirkka Saarinen ja asemansa puolesta Suomalais-Ugrilaisen Seuran esimies professori Ulla-Maija Forsberg sekä Kotikielen Seuran edustajina varaesimies Mari Siiroinen ja professori Jyrki Kalliokoski, on päättänyt myöntää August Ahlqvistin, Yrjö Wichmannin, Kai Donnerin ja Artturi Kanniston rahastojen käytettävissä olevasta vuoden 2018 tuotosta seuraavat palkinnot: Maximilian Murmannille 2 ooo euroa väitöskirjasta Inchoative emotion verbs in Finnish: Argument structures and collexemes, Duha Elsayedille 2 ooo euroa väitöskirjasta Agricolan pitää - nesessiiviverbi kielikontaktin ytimessä, LiisaMaria Lehdolle 2 ooo euroa väitöskirjasta Korpusavusteinen diskurssianalyysi japaninsuomalaisten kielipuheesta, Outi Tánczosille 2 ooo euroa väitöskirjasta $\mathrm{Me}$ diated discourses - ethnic minority media in linguistic and ethnic identity-building and language revitalization: Comparative case studies from Finno-Ugrian minority contexts ja Miia Karttuselle 2 ooo euroa väitöskirjasta No pittää kahttoo: Puhujan tulevan toiminnan ilmausten kielioppia ja pragmatiikkaa. Tuotosta jäljelle jäänyt 5 ooo euroa varattiin myöhempää käyttöä varten.

Kokouksessaan 14.-15. helmikuuta 2019 Sanakirjasäätiön rahaston lautakunta on päättänyt, että Sanakirjasäätiön rahaston vuoden 2018 jaettavissa olevasta tuotosta ja viime vuonna tehdystä varauk- sesta, jotka ovat yhteensä 3 297,07 euroa, jaetaan 3200 euroa apurahoina suomen ja sen sukukielten tutkimukseen. Apuraha julistetaan haettavaksi Kotikielen Seuran vuosikokouksessa ja päätös ilmoitetaan 4 . toukokuuta 2019. Apuraha voidaan jakaa usean hakijan kesken. Loput tuotosta varataan myöhempää käyttöä varten.

Kokouksessaan 30. tammikuuta - 13 . helmikuuta 2019 E. A. Saarimaan rahaston lautakunta, jonka muodostavat Kotikielen Seuran johtokunnan jäsenet, on päättänyt myöntää vuoden 2018 jaettavissa olevasta tuotosta ja viime vuonna tehdystä varauksesta, jotka ovat yhteensä 3750,17 euroa, neljä palkintoa: Olli Kupariselle 400 euroa artikkelista "Infinitiivien variaatio ja muutos Helsingissä" (Virittäjä 1/2018), Elina Vitikalle 400 euroa artikkelista "Hyperlinkkien funktiot ja kirjoittaja- ja lukijapositiot" (Virittäjä 2/2018), Irina Herneaholle 400 euroa artikkelista "Maahanmuuttodiskurssit eduskuntapuolueiden vuoden 2015 vaalimateriaaleissa" (Virittäjä 2/2018) ja Jenni Mikkoselle 400 euroa yhdessä Vesa Jarvan kanssa kirjoitetusta artikkelista "Lexical mixing in a conversation between old Helsinki slang speakers" (Palander, Riionheimo \& Koivisto toim. 2018: On the border of language and dialect). Loput tuotosta varattiin myöhempää käyttöä varten. Elina Vitikka ei osallistunut keskusteluun.

Kokouksessaan 7.-13. helmikuuta 2019 Lauri Kettusen rahaston lautakunta, johon ovat kuuluneet varaesimies Mari Siiroinen, professori Riho Grünthal ja maisteri Henri Satokangas, on päättänyt avata Lauri Kettusen rahaston vuoden 2018 jaettavissa olevasta tuotosta ja edellisvuoden varauksesta, jotka ovat yhteensä 4 998,82 euroa, 2 ooo euroa haettavaksi viron kielen opintoja varten. Lisäksi Lauri Kettusen rahaston lautakunta on päättänyt myöntää 2500 euroa kevään 2019 viron kielen opiskelijoiden Viroon suuntautuvan opintoretken rahoitukseksi. Loput tuotosta varattiin myöhempää käyttöä varten. 
Kokouksessaan 19. helmikuuta 2019 Hesteon koululaiskielirahaston lautakunta, johon ovat kuuluneet varaesimies Mari Siiroinen, Hesteon hallituksen jäsen Leena Paatero, maisteri Toni Suutari ja maisteri Henri Satokangas, on päättänyt varata vuoden 2018 tuotosta ja edellisvuosien varauksesta koostuvat 148,80 euroa myöhempää käyttöä varten.

Kuluneena toimintavuonna Seura on perinteiseen tapaan onnitellut ansioituneita jäseniään heidän merkkipäivinään sekä ottanut osaa poismenneiden jäsenten omaisten suruun.

Aikakauslehti Virittäjä ilmestyi vuonna 2018 neljänä vihkona, joissa oli yhteensä 628 sivua. Vuoden 2018 lopussa tilaajia oli 572. Päätoimittajana on toiminut dosentti Hanna Lappalainen. Toimitussihteerinä on työskennellyt maisteri Henna Leskelä. Kirjallisuusosastosta on vastannut tohtori Mikko T. Virtanen. Varapäätoimittajana ja verkkotoimittajana on toiminut tohtori Johanna Komppa. Virittäjän taloutta ja tilauksia on hoitanut maisteri Irina Herneaho.

Aikakauslehti Virittäjän toimitusneuvosto on kokoontunut 23. helmikuuta. Toimitusneuvoston puheenjohtajana on toiminut Seuran esimies, professori Pirjo Hiidenmaa. Muina jäseninä ovat toimineet dosentti Maria Ahlholm, dosentti Markku Haakana, professori Helena Halmari, tohtori Suvi Honkanen, professori Leena Huss, tohtori Vesa Jarva, professori Scott Jarvis, professori Lauri Karttunen, professori Leelo Keevallik, apulaisprofessori Leena Kolehmainen, dosentti Tommi Kurki, tohtori Niina Lilja, dosentti Liina Lindström, dosentti Krista Ojutkangas, dosentti Toini Rahtu, professori Jari Sivonen, dosentti Paula Sjöblom, professori Mirja Tarnanen, professori Stefan Werner ja professori Jussi Ylikoski.

Seuran nettovarallisuus tilinpäätöksessä on 202561,55 euroa. Seuran pitkäaikaisten sijoitusten arvoksi on vuoden 2018 tilinpäätökseen merkitty $176 \quad 482,25$ euroa. Pitkäaikaiset sijoitukset jakautuvat
Seuralle ja rahastoille seuraavasti: Kotikielen Seura 3,9 \%, Sanakirjasäätiö 36,1 \%, Lauri Kettusen rahasto 31,8 \%, E. A. Saarimaan rahasto $26,6 \%$ ja Hesteon koululaiskielirahasto $1,6 \%$. Seuran ja Virittäjän pankkitalletusten kokonaismäärä on ollut tilikauden päättyessä 34 348,79 euroa, joista Virittään osuus on ollut 31 611,32 euroa. Vuoden 2018 taseessa vastaavaa ja vastattavaa on kumpaakin 219 492,61 euroa.

Virittäjän tuotot olivat vuonna 2018 ilman avustuksia yhteensä 30 452,34 euroa. Nämä tuotot ovat kertyneet tilausmaksuista (30 292,50 euroa) ja korkotuotoista (159,84 euroa). Tieteellisten Seurain Valtuuskunnan myöntämä julkaisuavustus oli 19 ooo euroa. Näiden lisäksi oli muita tuottoja 7 415,90 euroa. Yhteensä Virittäjän tuotot olivat 56 868,24 euroa. Menoja kertyi 55 577,82 euroa. Suurimmat kulut aiheutuivat painatuksesta ja postituksesta (15 154,08 euroa) sekä henkilöstökuluista (33 220,23 euroa). Virittäjän tulos vuodelta 2018 osoittaa 1290,42 euron ylijäämää, joka palautetaan julkaisuavustuksen myöntäneelle Tieteellisten seuran valtuuskunnalle.

Seuran tuotot koostuivat pääosin jäsenmaksuista, jotka olivat 2 755,01 euroa. Seuran varsinaisen toiminnan kulut olivat 1351,47 euroa, ja ne koostuivat pääosin jäsenkokousten järjestämisestä sekä jäsen- ja viranomaismaksuista. Sijoitusja rahoitustoiminnan tulos oli 11 924,04 euroa, ja rahastoihin tuotoista siirrettiin 11904,80 euroa. Seuran tulos vuodelta 2018 on 1422,78 euroa ylijäämäinen.

Kotikielen Seuran ja Virittäjän vuoden 2018 yhteinen tilinpäätös osoittaa tuottoja 71 733,53 euroa, kuluja 57 115,53 euroa ja rahastoille siirrettävää tuottoa 11 904,80 euroa. Ylijäämäksi muodostuu 2 713,20 euroa.

Helsingissä 13. maaliskuuta 2019

Henri Satokangas Kotikielen Seuran sihteeri seura@kotikielenseura.fi 